\title{
The relationship between entrepreneurial competencies and the recurring entrepreneurial intention and action of existing entrepreneurs
}

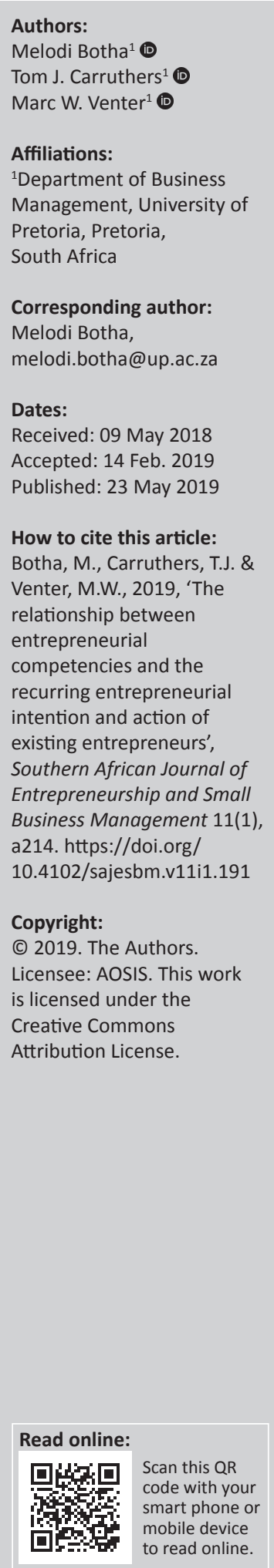

Background: Many scholars focus their research efforts on the entrepreneurial intention of students and non-entrepreneurs, yet most of these scholars found empirical evidence that intention does not necessarily lead these individuals to start businesses (entrepreneurial action). Possible explanations for this could be that: (1) previous studies focused on the wrong samples; (2) they measured entrepreneurial intention as a single construct; and (3) there is a missing link between intention and action.

Aim: To address these gaps, we determine the relationship between recurring entrepreneurial intention attitudes and action as well as entrepreneurial intention behaviours and action of 154 existing entrepreneurs in South Africa. By focusing on a sample of existing entrepreneurs who have already started a business, we shed light on the set of entrepreneurial competencies as a missing link between intention and action. This article is of academic importance as it focuses on the recurring process that entrepreneurs follow instead of the initial intention that is often overemphasised in literature. As far as could be determined, no other studies have investigated the relationships between entrepreneurial competencies, recurring entrepreneurial intention attitudes, recurring entrepreneurial intention behaviours and recurring entrepreneurial action.

Setting: The research was conducted on 154 existing entrepreneurs in South Africa.

Methods: A self-administered survey was used and the findings indicate that entrepreneurial competencies have a positive relationship with recurring entrepreneurial action, recurring entrepreneurial intention behaviours and recurring entrepreneurial intention attitudes.

Results: There was no significant relationship between entrepreneurial action and recurring entrepreneurial intention behaviours. This is an unexpected finding as a positive relationship was expected for a sample that had prior entrepreneurial experience and already engaged in prior behaviours. However, this study contributes to the entrepreneurial intention-action literature by suggesting that existing entrepreneurs with recurring intention should also be measured in these relationships, in comparison to other research that mainly focused on the intentions of students and non-entrepreneurs.

Conclusion: The practical contribution of this article is in the identification of specific entrepreneurial competencies, such as creative problem-solving, opportunity recognition and value creation that existing entrepreneurs relied on the most when engaging in entrepreneurial action. Potential, nascent, existing and serial entrepreneurs could focus on these competencies if they wish to engage in entrepreneurial action as well as recurring entrepreneurship.

Keywords: Entrepreneurial competencies; recurring entrepreneurial intention behaviours; recurring entrepreneurial intention attitudes; recurring entrepreneurial action; survey; South Africa.

\section{Introduction}

Intentions are indicators of the degree to which individuals are willing to put in an effort to perform a specific behaviour (Ajzen 1991:181); more specifically, entrepreneurial intentions have been found to mediate the behaviours of an entrepreneur to start a business (Kautonen, Gelderen and Fink 2015:657). Thompson (2009) defines entrepreneurial intention as the self-acknowledged belief that an individual will start a new business in future. However, Herrington, Kew and Mwanga (2017) point out that the entrepreneurial intention rate of $10.1 \%$ in South Africa is considerably lower than that of other African countries and almost half when compared to developed countries. Although numerous studies have been conducted on the determinants of 
entrepreneurial intention (Choo \& Wong 2006:47-64; Mitchell et al. 2000:974-993; Schlaegel \& Koenig 2014:291-332), limited research exists regarding the behaviours that lead to entrepreneurial action. Segal, Borgia and Schoenfeld (2005:52) agree that often the intention is there for individuals to become entrepreneurs; yet it is by no means true that action will automatically follow on from this intention (Fayolle \& Degeorge 2006:78). Nabi, Walmsley and Holden (2013:2) and Smith and Beasley (2011:725) concur and state that students' ratings of intention towards self-employment and actual business start-up (action) are not aligned. In most of these previous works, entrepreneurial intention was treated and measured as a single construct (Fayolle \& Degeorge 2006; Thompson 2009); intention attitudes and behaviours were not measured. Furthermore, previous research on entrepreneurial intention has mainly focused on measuring the entrepreneurial intentions of students (Nabi et al. 2013; Smith and Beasley 2011) and non-entrepreneurs such as managers (Thompson 2009). Could it be that we have been focusing on the wrong sample when measuring entrepreneurial intention and action? In early years, MacMillan (1986:241) determined that for scholars to really learn about entrepreneurship, they need to study entrepreneurs who engage in recurring entrepreneurship, for example when existing entrepreneurs start another business. It was found that recurring entrepreneurs measured much higher in certain characteristics compared to those who only started one business (Boyatzis 1982:139; Carland, Carland \& Stewart Jr 2000:15). At the same time, Scott and Rosa (1996:86) suggested that researchers should study recurring entrepreneurs because they are a core part of understanding the entrepreneurial process. Westhead, Ucbasaran and Wright (2005) agree that there is a need to learn from the previous independent business ownership experiences of existing and serial entrepreneurs. One way of doing this is by studying existing entrepreneurs with the intention of starting another business and measuring the relationship between recurring intention and action.

Entrepreneurial action is defined as the process of bringing together actions that are continuous and interdependent into sequences that produce sensible results (Weick 1979:3). The two action models this article incorporates are the rubicon model of action (RMA) and the action regulation theory (ART) (Frese \& Zapf 1994:271-340; Gollwitzer 1990:53-92). The ART includes antecedents of action: (1) the goal (intention of the individual); (2) action knowledge (to practically apply competencies such as opportunity recognition, networking and resource leveraging); and (3) self-efficacy (one's belief in his or her competencies) (Frese \& Zapf 1994:273-278). The ART and personality theory suggest that the missing link between intention and action might be entrepreneurial competencies, as they are important for businesses to succeed (Morris et al. 2013b:354). Although various competencies are mentioned in the literature, Morris et al. (2013b:362) were able to identify specific competencies that were important for entrepreneurial action. These competencies are consistent with those described in other research (Duckworth \& Quinn 2009:167; Liñán, Rodríguez-Cohard \& Rueda-Cantuche
2011:214; Morris et al. 2013b:357; Tang, Kacmar \& Busenitz 2012:82). For the purpose of this article, seven of the entrepreneurial competencies as identified by Morris Kuratko and Cornwall (2013a), Morris et al. (2013b) were tested as a set. Zahra, Nielsen and Bogner (1999:175) are of the opinion that the competencies of existing entrepreneurs who have recurring entrepreneurial intentions or who have taken recurring actions may have developed over time, potentially through the experience of operating their first business.

In this article, three research problems have been identified. Firstly, as there is often the intention to start a business, but action does not necessarily follow from the intention (Segal et al. 2005:52; Shane, Locke \& Collins 2003:271), it might be that students, non-entrepreneurs and potential entrepreneurs are not the samples that should be focused on when investigating the intention-action relationship. Furthermore, most of the previous studies measured entrepreneurial intention as a single construct with items testing entrepreneurial intention attitudes. In this article we measure entrepreneurial intention by testing both entrepreneurial intention attitudes as well as entrepreneurial intention behaviours. Lastly, as far as could be determined, no studies have investigated the relationships between entrepreneurial competencies, recurring entrepreneurial intention and recurring entrepreneurial action of existing entrepreneurs. Morris et al. (2013a:352-369) investigated the role of competencies but did not specifically focus on recurring entrepreneurial intention and recurring entrepreneurial action.

We address these problems by investigating the following research objectives:

- to determine the relationship between recurring entrepreneurial intention (attitudes and behaviours) and recurring entrepreneurial action of existing entrepreneurs

- to determine the relationship between entrepreneurial competencies and recurring entrepreneurial intention (attitudes and behaviours) of existing entrepreneurs

- to determine the relationship between entrepreneurial competencies and recurring entrepreneurial action of existing entrepreneurs

- to determine which entrepreneurial competencies the existing entrepreneurs relied on the most when engaging in recurring entrepreneurial action.

This article makes several contributions. It contributes to the entrepreneurial intention-action literature by investigating more complex relationships between recurring intention (attitudes and behaviours) and action. This article highlights that students or novice entrepreneurs are not necessarily the only samples that should be focused on when measuring entrepreneurial intention-action relationships, and it sheds light on understanding these relationships from an existing entrepreneur sample that has already taken the leap towards entrepreneurial action. In this article we argue that it might be worth focusing on recurring entrepreneurs, as their entrepreneurial experience can teach us which competencies we should rely on when engaging in entrepreneurial action. 
The article contributes to entrepreneurial intention as a construct by measuring both entrepreneurial intention attitudes as well as entrepreneurial intention behaviours. By doing so we can test the individual relationships of recurring entrepreneurial intention attitudes and recurring entrepreneurial intention behaviours with recurring action. In fact we did find that a positive relationship exists between recurring entrepreneurial intention attitudes and recurring action but not between recurring entrepreneurial intention behaviours and recurring action. This study suggests that future studies on entrepreneurial intention should measure this construct by testing attitudes and behaviours separately.

This study contributes to entrepreneurial education research by further testing the competencies that are identified by Morris et al. (2013b:352-369) but in a recurring developing country entrepreneurship context. Most of the research on entrepreneurial competencies is conducted in developed countries (Morris et al. 2013a, 2013b; Liñán et al. 2011), and we answer the call for more entrepreneurship research in an African context (George et al. 2016). Lastly, the necessary entrepreneurial competencies for recurring entrepreneurial action that existing entrepreneurs rely on are identified, providing a more conclusive understanding of which entrepreneurial competencies are necessary for recurring entrepreneurs. Identifying and measuring entrepreneurial competencies have valued consequences for the advancement of entrepreneurial education and improvement of the practice of entrepreneurship (Morris et al. 2013b:353).

This article is structured as follows: a literature review that is focused on entrepreneurial intention and recurring intention as well as associated frameworks, entrepreneurial action (and recurring action) and entrepreneurial competencies. Hypotheses are formulated based on previous literature. This is followed by a discussion of the methodology conducted for the study. The article then reports on the study's findings, followed by a final discussion of those results and a conclusion.

\section{Literature review}

\section{Recurring entrepreneurial intention}

Entrepreneurial intention has been an important area for researchers and studies (Shapero \& Sokol 1982:72-90), and several studies have incorporated the theory of planned behaviours (TPB) into different events for predicting intentions and behaviours(Al-Debei, Al-Lozi \& Papazafeiropoulou 2013:43-54; Francis et al. 2004). The TPB seeks to explain which factors (motivational and ability) influence an individual's behaviours. The other main theory for predicting entrepreneurial intentions is the entrepreneurial event model (EEM) (see Figure 1), which correlates highly with TPB (Ajzen 1991:179-211; Shapero \& Sokol 1982:72-90). In this article the antecedents of the TPB and EEM on entrepreneurial intention are used as the underlying

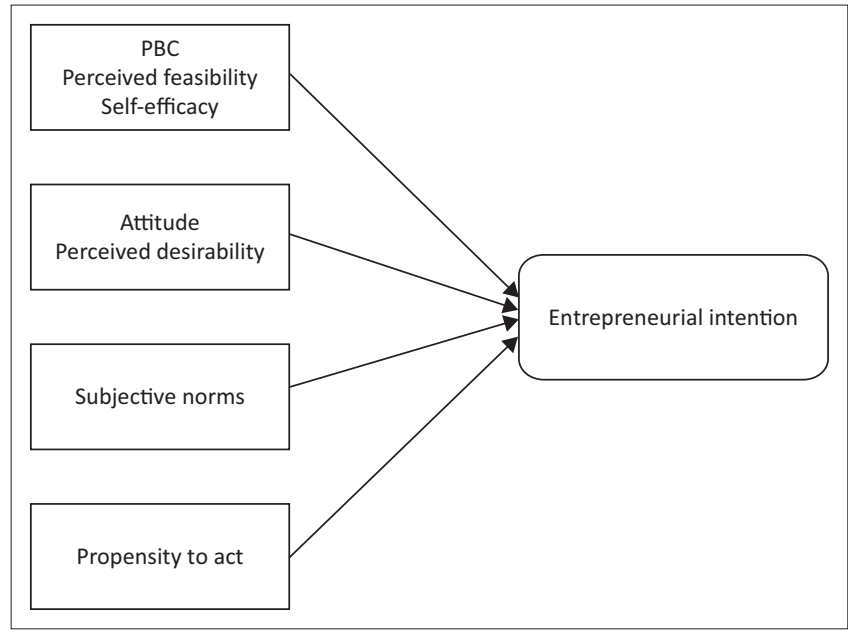

Source: Adapted from Krueger, N.F., Reilly, M.D. \& Carsrud, A.L., 2000, 'Competing models of entrepreneurial intentions', Journal of Business Venturing 15(5-6), 416, 418. https://doi. org/10.1016/S0883-9026(98)00033-0

$\mathrm{PBC}$, perceived behavioural control.

FIGURE 1: The theory of planned behaviour and Entrepreneurial Event Model influences on entrepreneurial intention and action.

framework that will influence the intention-action relationship. Among the more important variables of these theories are the perceived behavioural control (PBC) and the perceived feasibility of the individual. This is the belief that the individual has in his or her own abilities to perform a certain behaviour (Ajzen 1991:185; Krueger, Reilly \& Carsrud 2000:149), and our contention in this article is that this behaviour can be measured as one of the entrepreneurial intention constructs, in particular, entrepreneurial intention behaviours. Perceived behavioural control and perceived feasibility are often compared, while social norms and the attitude towards the behaviours are similar to perceived desirability (Krueger et al. 2000:419). This attitude towards behaviours is the positive or negative view the individual has of becoming an entrepreneur (Ajzen 1991:182-188). Often a change in attitude is significant in changing behaviours and intentions and can have an influence on subsequent entrepreneurial activities (Krueger et al. 2000:414). We agree with these scholars that attitudes can be considered a significant determinant for influencing behavioural intentions (Boyd \& Vozikis 1994:64). When explaining the similarity between PBC, perceived feasibility and selfefficacy, Rodrâiguez-Cohard and Rueda-Cantuche (2011:199) stated that ' $[i] n$ all three instances, the important thing is the sense of capacity regarding the fulfilment of firm creation behaviours'.

A recurring entrepreneur can be defined as an entrepreneur who through previous experiences of business has gathered the necessary information to enable him or her to effectively identify opportunities and be able to learn from the mistakes of previous business experience (Westhead et al. 2005:396). These opportunities could be to start another business (recurring entrepreneurial action) or to develop new areas within an existing business. At the same time the terms 'recurring' and 'serial' entrepreneurs, referring to those who start multiple businesses, are often used interchangeably. 
The importance of studying serial entrepreneurs is emphasised by Simmons et al. (2016:606), who suggest that the experience that an entrepreneur gains from starting and running a business influences the future behaviours of the entrepreneur. As far as can be determined, no other studies have incorporated the full TPB or EEM when predicting recurring entrepreneurial intention. There is, however, evidence of studies that draw on certain variables, such as self-efficacy and attitude influence from those theories (Krueger et al. 2000:414). Wood and Bandura (1989:364-365) argue that people's self-efficacy is easily influenced by previous experience and can affect and forecast succeeding motivation towards certain behaviours. In this article, these behaviours might be recurring entrepreneurial intention. We draw evidence from these studies that suggests that there is a positive relationship between prior entrepreneurial experience and self-efficacy and that the higher the entrepreneurial self-efficacy before exiting the business, the higher the subsequent entrepreneurial intention (Hsu 2011:21; Hsu, Wiklund \& Cotton 2017:23). As prior entrepreneurial experience, self-efficacy and entrepreneurial intention are strongly correlated, it is our belief that the recurring entrepreneurial intention of existing entrepreneurs might be high because of their prior entrepreneurial experience and self-efficacy levels.

\section{Recurring entrepreneurial action}

Entrepreneurial action is the process of transitioning to business ownership and is often referred to as business start-up (Jayawarna, Rouse \& Macpherson 2014:286). McMullen (2015:652) further goes on to say that entrepreneurial action is an entrepreneurial process involving numerous transactions and interactions with various stakeholders, each transaction involving an exchange between parties and entrepreneurial action of turning an idea into a viable product offering. Most studies on entrepreneurship acknowledge that entrepreneurial action is a process rather than a single step (Baron 2007:167; Gartner 1985:697; Gollwitzer 1990:55; Kautonen et al., 2015:659; Weick 1979). Similarly, it is said that creating a new business involves multiple activities that are complex, interdependent and can be performed in any sequence (Lichtenstein et al. 2007:239). Accordingly, Frese (2009:438) states that all definitions of entrepreneurship ultimately imply actions. Some of the definitions are based on theoretical frameworks. One such framework is the RMA proposed by Gollwitzer (1990:53-92). This model seeks to explain actions as specific phases that start with one's desire towards a behaviour before a goal is set and end with one's evaluation of the achieved goal (Gollwitzer 1990:55).

Action regulation theory is another framework that posits that action can progress from a goal to a plan, leading to execution and feedback. In this manner, it overlaps greatly with the RMA. The first step in the process is goal development. Like the RMA, the goal starts out as a wish that the individual has and is pulled by the individual's cognitive and motivational aspects. Following this in the process is orientation, whereby the individual orientates himself or herself towards the goal, which is a novelty for him or her and the first level of analysing situational and object conditions. For this to happen, the individual will need the antecedents of action. The first is action knowledge, which is the knowledge a person, gained through competencies, has about the potential actions and the environment they act in. In other words, it refers to what they have to do to take action and how they practically apply the competencies to take action, for example being able to recognise a new opportunity and knowing how one should take advantage of that opportunity. The next antecedent is self-efficacy, which is mentioned previously as a determinant of entrepreneurial intention.

The subsequent step in the process is plan generation and decision-making. A plan is usually developed before the action is performed and is also a known competency (Anokhin, Grichnik \& Hisrich 2008:130). Lastly, the individual executes the action or behaviour (Frese \& Zapf 1994:273-278). Therefore competencies, specifically entrepreneurial competencies, are included and explored in the relationship with recurring entrepreneurial intention and recurring entrepreneurial action.

While Kautonen et al. (2015:660) suggest that entrepreneurial action does not follow entrepreneurial intention, at some point the entrepreneur must have taken action intentionally to start a business. In their study, Kolvereid and Isaksen $(2006: 873,882)$ did not find support for the contention that intentions predicted entry into self-employment. However, they did find that the entrepreneurial process is in many cases an ongoing process. A study found that one in three entrepreneurs who stated they had recurring entrepreneurial intention when their business closed did own a business again in the following seven years (Ucbasaran, Westhead \& Wright 2009:107). Evidence from Guerrero and PeñaLegazkue (2018:1) states that more than $25 \%$ of entrepreneurs end up re-engaging in business creation after having previous business failures and then proceeding to start up a new business. Further, they proposed that increased levels of entrepreneurial experience leads to a greater chance of becoming a serial entrepreneur (Stam \& Schutjens 2006:7, 11).

\section{The relationship between recurring entrepreneurial intention and action}

Because there will always be some level of intention that precedes action, it is important to show the correlations between the intention and action models (Kautonen et al. 2015:660). The RMA links with the TPB and the EEM in the sense that the pre-actional phase is the intention to engage in a behaviour, and the actional phase links with entrepreneurial action by actually performing the behaviours that were intended.

Thus, in the pre-actional phase it is said that one must plan to start taking action (Gollwitzer 1990:57). The RMA state that 
when entrepreneurial implementation difficulties arise, people become concerned about how to achieve the intended goal and consider giving up on it. Furthermore, the model suggests that intention becomes action when the commitment towards the goal is strong.

Wright, Robbie and Ennew (1997:252) point out that entrepreneurs do not stop and that they continue the process of entrepreneurship over many years. The TPB states that it should be expected that intentions will impact action to the degree that the individual possesses behavioural control (skills), and performing an action should increase the behavioural control. Further, the model states that selfefficacy with intention directly predicts action (Ajzen 1991:181-196). In their study, Bagozzi, Baumgartner and Yi (1989:44, 59) claim that the best predictor of planned behaviour (action) is intention, which they found significant support for using multiple studies. Lastly, incorporating the TPB in their study, Krueger et al. (2000:414) state that a strong entrepreneurial intention should produce an attempt to start a business. The TPB suggests that a person's intention is based on his or her potential behaviour, which in turn can be influenced by the attitudes a person has (Kautonen et al. 2015:658). Therefore when measuring intention (refer to Figure 2) in this article, we distinguish between entrepreneurial intention attitudes and entrepreneurial intention behaviours.

Entrepreneurial intention attitudes can be described as the way an individual feels towards the work, risk, independence and income from being self-employed (Douglas \& Shepherd 2002:82). By contrast, entrepreneurial intention behaviours can be described as independent thinking, risk-taking and radical thinking (Eroglu \& Piçak 2011:146). It is important to distinguish between feelings and thinking when measuring an individual's entrepreneurial intention. Thinking, which is described as intentional behaviour, is a prerequisite for entrepreneurial action to occur. Based on the discussion above we assume that if an entrepreneur has recurring entrepreneurial intention attitudes and behaviours it most probably will lead to recurring entrepreneurial action. Figure 2 suggests how recurring entrepreneurial intention and its antecedents influence recurring entrepreneurial action.

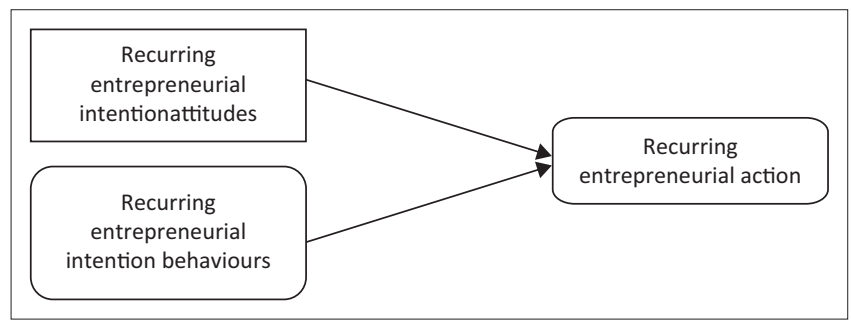

Source: Adapted from Ajzen, I., 1991, 'The theory of planned behavior', Organizational Behavior and Human Decision Processes 50(2), 182. https://doi.org/10.1016/07495978(91)90020-T; and Kautonen, T., Gelderen, M. \& Fink, M., 2015, 'Robustness of the theory of planned behavior in predicting entrepreneurial intentions and actions', Entrepreneurship Theory and Practice 39(3), 674. https://doi.org/10.1111/etap.12056

FIGURE 2: The relationship between recurring entrepreneurial intention and recurring entrepreneurial action.
Thus, on the evidence provided by the literature, we propose the following hypotheses:

$\mathbf{H}_{1 \mathbf{a}}$ : There is a positive relationship between recurring entrepreneurial intention behaviours and recurring entrepreneurial action.

$\mathbf{H}_{1 \mathrm{~b}}$ : There is a positive relationship between recurring entrepreneurial intention attitudes and recurring entrepreneurial action.

\section{Entrepreneurial competencies}

Entrepreneurial competencies as defined by Ahmad (2007:22) are the 'individual characteristics that include both attributes and behaviours, enabling the entrepreneur to achieve and maintain business success'.

Anokhin et al. (2008:126) found that entrepreneurs with higher levels of general skills, such as communication skills and networking, are more likely to start multiple businesses. This is supported by the personality theory, as it considers the motivations and traits of an entrepreneur holds (Robinson et al. 1991:14). Boyatzis (2008:10) and Mischel (1973:267) made important breakthroughs in personality theory research and determined that looking at competencies as opposed to the traditional traits and motivations was a far better method for assessing an individual's likelihood of success than solely looking at their personality. As entrepreneurial competencies are comprised of opportunity identification, networking skills and risk-taking propensity this makes the business and entrepreneur more adaptable to environmental changes, consumer preferences, technological developments and competitor moves (Kellermanns et al. 2008:5). Brandstätter (2011:225-226) was able to confirm that many personality constructs and competencies were indeed directly linked to the intention that an entrepreneur had.

For the purpose of this article, seven entrepreneurial competencies were included as a set of competencies, as they were identified as the ones that Morris et al. (2013b:352369) suggested would lead to entrepreneurial action. In another study, these same competencies were positively related to entrepreneurial intention (Rodrâiguez-Cohard \& Rueda-Cantuche 2011:195-218). They are as follows:

- opportunity recognition: the ability to filter and refine information effectively and quickly in order to be able to respond to favourable circumstances that could result in a profitable outcome (Wihler et al. 2017:13921393).

- perseverance: the cognitive ability or characteristic that enables individuals to continue their efforts and exhibit persistent behaviours to overcome setbacks, uncertainty and resistance (Brinckmann and Kim, 2015:155).

- problem-solving: as Spivack, McKelvie and Haynie (2014:661) point out, a major part of being an entrepreneur is being able to 'accomplish opportunities' that would not have come around were it not for problem-solving.

- resource leveraging: allowing entrepreneurs to access resources that are not theirs in order to achieve the goals of the organisation (Morris et al. 2013a:47). 
- value creation: Lee and Lee (2015:893) state that it is important that an entrepreneur be able to 'harvest the value' somewhere, in order to make the recurring process worthwhile and to actually create value.

- networking: (Morris et al. 2013b:354) define networking as the interaction and social skills between individuals that allows for the establishment and development of relationships that help with the advancement of careers and work.

- self-efficacy: the ability to maintain a sense of selfconfidence regarding one's ability to accomplish a task or attain a level of performance (Morris et al. 2013b:352).

\section{The relationship between entrepreneurial competencies and recurring entrepreneurial intention}

The preceding discussion confirms that self-efficacy and perceived behavioural control from the theory of planned behaviours and the entrepreneurial event model link competencies to entrepreneurial intention.

From the personality theory, Chell (2008:157) argues that competencies can be developed from experiences in the real world, such as previous entrepreneurial experience. This can also come from an entrepreneur's personality traits, which are often relevant in being able to predict entrepreneurial intention (Brandstätter 2011:222). A person's personality can include various factors, which can encompass a person's attitudes as well as their abilities or competencies (Boyd \& Vozikis 1994:69). Zahra et al. (1999:175) state that for further activities to be successful, there must be some form of competence development, and this development can often come through learning in a business (Boyatzis 2008:10).

Previous research suggests that the experience an entrepreneur gains by starting and running a business will influence their future behavioural intention and attitudes (Ucbasaran, Westhead \& Wright 2008:169).

Figure 3 indicates the relationship between behaviours and attitudes of entrepreneurs and how certain competencies within this relationship influence the recurring entrepreneurial intention. It is expected that recurring entrepreneurs will draw upon their previous business

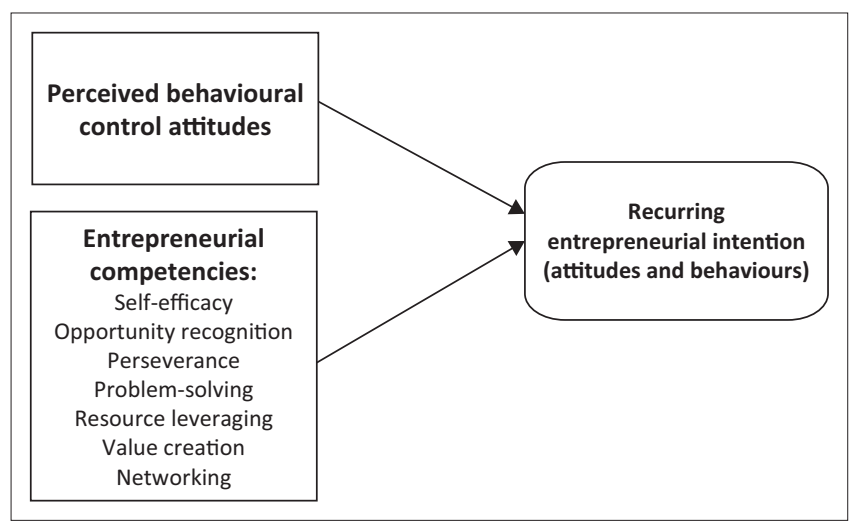

Source: Adapted from Gielnik et al. 2015:94 and Miralles, Giones and Riverola 2016:800 FIGURE 3: The relationship between entrepreneurial competencies and recurring entrepreneurial intention. experience; they will also exhibit more effective opportunity recognition and information search than start-up and novice entrepreneurs (Westhead et al. 2005:398). This implies that superior entrepreneurial intention often leads to recurring entrepreneurial intention.

Thus, based on the evidence from the literature surrounding competencies and entrepreneurial intention, we hypothesise that:

$\mathbf{H}_{2 \mathrm{a}}$ : There is a positive relationship between a set of entrepreneurial competencies and recurring entrepreneurial intention behaviours.

$\mathbf{H}_{2 b}$ : There is a positive relationship between a set of entrepreneurial competencies and recurring entrepreneurial intention attitudes.

\section{The relationship between entrepreneurial competencies and recurring entrepreneurial action}

Action regulation theory suggests that the starting point of actions includes intentions, but to achieve action other action regulatory factors are necessary to translate intentions into actions (Frese \& Zapf 1994:273). Gielnik et al. (2015:69-94) used ART to test whether training could increase the antecedents of individuals and whether those antecedents led to entrepreneurial action. To understand the set of competencies measured in this article, the relationship between each of the individual entrepreneurial competencies and entrepreneurial action is briefly discussed.

Opportunity recognition: Pretorius and Le Roux (2011:1-13) suggest that even though entrepreneurs are engaged in an existing business they are still prepared to take action towards a new one by focusing on opportunity recognition.

Perseverance: If entrepreneurs persevere with their ventures, they are more likely to have confidence in their beliefs and the prospect of a new venture, compared to those entrepreneurs who do not persevere as confidently with a new venture (Hayward et al. 2010:5).

Creative problem-solving: It is interesting that Anokhin et al. (2008:139) note that in novice entrepreneurs, if their problem-solving is high, they are less likely to become recurring entrepreneurs. This is because they will have often invested their full commitment and are confident in their current strategy through problem-solving. Contrastingly, if the entrepreneur's problem-solving is high but still develops through their experience, the results may differ and recurring action may be taken (Presutti, Onetti \& Odorici 2008:14).

Value creation: In previous research, there was often a limitation on recurring entrepreneurs in terms of their value creation (Alsos, Kolvereid \& Isaksen 2006:47). This is because they have shared value creation priorities with their old and new businesses. This is important for this study as it contributes to supporting the theory that value creation is still important for recurring entrepreneurs, be it through the new or old business. 
Resource leveraging: Regarding resource leveraging, Alsos et al. (2006:46) were able to determine that for new ventures, entrepreneurs who were taking recurring action were much more capable of obtaining resources compared to first-time entrepreneurs.

Networking: The competency of networking skills can be developed through education and practice such as a previous business venture. In support, Smeltzer, Van Hook and Hutt (1991:11) found that entrepreneurs' access to networks is a significant factor in predicting new business ventures. Most importantly, there is evidence that entrepreneurs who more frequently use networks regarding their business are more likely to engage in recurring entrepreneurship (Wiklund \& Shepherd 2008:707). Support for the relationship between the other five entrepreneurial competencies and recurring entrepreneurial action was also found and is briefly summarised.

Self-efficacy: Experience in overcoming setbacks through continuous determination is required to increase one's self-efficacy (Wood \& Bandura 1989:364). As a result of the success in an activity and increased self-efficacy, individuals are more likely to engage in similar behaviours or activities (Bandura 1991:257-259). In support, Hsu (2011:21) found significant evidence for the relationship between entrepreneurial self-efficacy and subsequent entrepreneurial intention. Furthermore, it is argued that a central part of self-efficacy is shaped by having successfully performed behaviours in the past (Bandura 1977:194). Segal et al. (2005:54) noted that through self-efficacy, recurring performance is more likely from an entrepreneur. This strength is determined by the goal's desirability and feasibility (self-efficacy) (Gollwitzer 1990:57). Thus, selfefficacy influences both intentions and actions. Finally, Presutti et al. (2008:4) point out that for new businesses to be successful in taking action, the competencies that are present in recurring entrepreneurs are learnt from their previous ventures, which are vital. Thus, based on this evidence, we hypothesise that:

$\mathbf{H}_{3}$ : There is a positive relationship between a set of entrepreneurial competencies and recurring entrepreneurial action.

\section{Methodology \\ Research design and sampling}

The research design consisted of a quantitative approach whereby a structured research questionnaire (survey) was administered. The target population consisted of existing entrepreneurs who had started their own businesses and operated these businesses in South Africa. Herrington et al. (2017) define existing entrepreneurs as start-up (early stage) or established entrepreneurs who own a business venture (i.e., exploited an entrepreneurial opportunity), regardless of whether they are early-stage entrepreneurs or established entrepreneurs (who started a business many years ago). The study focused on the entrepreneurial competencies, recurring entrepreneurial intention and recurring entrepreneurial action, of individual entrepreneurs who had taken previous entrepreneurial action, thus the individual entrepreneurs were the units of analysis.

\section{Sampling method, selection criteria and sample size}

This study made use of a non-probability, convenience sampling method in which respondents were chosen based on their convenience (Cooper \& Schindler 2014:359). In order to achieve representivity, the following selection criteria were used to include the respondents in the sample:

- The respondents must be existing entrepreneurs (owning a business at the time of the research).

- The respondents could either be:

- early-stage or start-up entrepreneurs - owned a business for 3 years or less (Herrington et al. 2017)

- established entrepreneurs - owned a business for 3 years or longer (Herrington et al. 2017).

- The respondents must be business owners within the borders of South Africa.

- The respondents could operate in any industry and in any of the nine provinces in South Africa.

- As the emphasis of this study is on determining recurring intention and action, the respondents should have answered the screening question: Have you taken any action to start another business?

Furthermore, the respondents for this study consisted of entrepreneurs with businesses that had available e-mails listed on South African business directories. These directories included the Cylex Business Directory, Brabys, Yalwa, South African Business Directory, Gauteng Business Directory and Business Directory. It was specified in the e-mail and consent form that the survey would be required to be completed by the owner of the business. This allowed contact with numerous respondents to increase the response rates for the survey, to compensate for the expected low response rate of e-mail surveys. An attempt was made to limit sample selection bias by sending e-mails to all those respondents with available e-mails and not specifically selecting which respondents to send the survey to (Creswell \& Clark 2011:102).

This study aimed to achieve a minimum sample size of 200 respondents, and therefore 260 surveys were distributed. The number of usable questionnaires was 154, and the response rate was $59 \%$.

\section{Data collection}

\section{Pretesting}

The pretesting of the data collection instrument was done in two phases. The first phase was a collaborative participant pretesting done with five participants who came from the target population of current entrepreneurs who had previously taken entrepreneurial action (Cooper \& Schindler 2014). 
The second phase of pretesting was a time and survey method test. We tested the viability of our self-administered questionnaire, as well as the time taken to complete the questionnaire (Cooper \& Schindler 2014). No substantial changes were needed for either phase of pretesting.

\section{Data collection}

Data was collected during September to November 2017. The predominant data collection method used (250 responses) was a self-administered Internet survey that was hosted on Qualtrics. The survey link was e-mailed to the respondents. Internet survey was an appropriate choice of survey method as it allowed an increase in the volume of the responses received, as the respondents were otherwise inaccessible (Cooper \& Schindler 2014:228).

The second data collection method used was a selfadministered intercept survey. The questionnaire was handed out to 10 respondents who were in close proximity and were listed in the previous directories. Respondents were asked to fill in the questionnaire and have it ready for collection the following week.

\section{Survey measures}

\section{Recurring entrepreneurial intention}

Recurring entrepreneurial intention behaviours were measured using the scale developed by Kautonen et al. (2015:681) using a five-point Likert scale, which required respondents to rate three statements about themselves from 1 (strongly disagree) to 5 (strongly agree). Recurring entrepreneurial intention attitudes were measured using a semantic differential scale rating six opposite word pairs from 1 to 7 , such as 'attractive' and 'unpleasant', relating to intention. A high score on both scales indicates that the respondent has a strong intention to start another business as well as having positive attitudes towards the idea of starting another business. An averaging method was used to calculate the composite scores across the scale items.

The Cronbach's alpha for recurring entrepreneurial intention behaviours was 0.95, and for recurring entrepreneurial attitudes the Cronbach's alpha was 0.96. These values indicate that there was acceptable internal consistency; they were in line with previous research conducted by Kautonen et al. (2015:665).

\section{Recurring entrepreneurial action}

Recurring entrepreneurial action was measured with the scale used by Kautonen et al. (2015:681).

Respondents were required to rate statements about starting another business from 1 (very little) to 5 (a great deal), with an option of 6 (don't know). A high score on this scale indicated that the respondent had taken a great deal of recurring action. An averaging method was used to calculate the composite score across the scale items.
The Cronbach's alpha for recurring entrepreneurial action was 0.88 , which indicates that there was acceptable internal consistency, and this value is also in line with previous research conducted by Kautonen et al. (2015:665).

\section{Entrepreneurial competencies}

The seven independent competencies that were used were taken from the study by Morris et al. (2013b:359).

These authors determined the core list of entrepreneurial competencies by implementing a multi-round Delphi technique. Each of these competencies was also supported by using other scholars' measuring scales, for example:

- Opportunity recognition was measured using the scale as adapted by Tang et al. (2012:82).

- Perseverance was measured using the scales that were adapted by Duckworth and Quinn (2009:167) and Hmieleski and Corbett (2006:52).

- Creative problem-solving was measured using the scales developed by Hmieleski and Corbett (2006:52) and Zampetakis and Moustakis (2006:418).

- Resource leveraging was measured using scales by Politis, Winborg and Dahlstrand (2012:667-668) and Winborg and Landström (2001:247).

- Value creation was taken from the scale used by Dyer, Gregersen and Christensen (2008:338).

- Networking was measured by adapting the scale by Forret and Dougherty (2001:306-307).

- Self-efficacy was taken from the scale used by Liñán et al. (2011:214).

The entrepreneurial competencies were all measured using a five-point Likert scale ranging from 1 (strongly disagree) to 5 (strongly agree). An averaging method was used to calculate the composite scores across each scale item.

Apart from resource leveraging, each entrepreneurial competency had a Cronbach's alpha value of above 0.7, which suggests acceptable internal consistency. With resource leveraging included, the Cronbach's alpha value across all the competencies was 0.934 , which suggests acceptable internal consistency.

\section{Findings}

\section{Demographic profile of respondents}

From the total sample of $n=154,102$ were male and 52 were female, which equated to the majority of the respondents being male (66\%). The respondents held the following qualifications: $26.3 \%$ held a Grade 12 certificate; $61.8 \%$ of respondents held a qualification above Grade 12; 15.1\% held an honours degree; $10.5 \%$ held a master's degree; and 1.97\% held a doctoral degree. Further, the majority of the respondents had started two to three businesses $(48 \%)$, where $9 \%$ of the respondents had between four and six businesses, and 7\% of the respondents had started more than six businesses. The majority of the sample were serial entrepreneurs (64\%), 
while $36 \%$ of the respondents had one business. The majority of the respondents were from Pretoria (35.3\%) and Johannesburg (35.3\%), whereas the rest of the candidates were from the other areas in South Africa (22.66\%), and 10 international candidates $(6.66 \%)$ were surveyed.

\section{Confirmation of the constructs}

Overall, the perception of recurring entrepreneurial intention behaviours was lightly negative for entrepreneurs (mean $[\mathrm{M}]=2.91$, standard deviation $[\mathrm{SD}]=1.45$ ). Contrastingly, the data suggests that entrepreneur attitudes about recurring entrepreneurial intention were overall positive $(\mathrm{M}=4.46$, $\mathrm{SD}=2.06)$. Following this, the data suggests that recurring entrepreneurial action was slightly positive $(\mathrm{M}=3.29$, $\mathrm{SD}=1.14)$. This means that on average entrepreneurs had taken a great deal of action in starting another business. Furthermore, to determine which competencies the existing entrepreneurs relied on most when engaging in recurring action, we measured the composite scores of each individual competency as shown in Table 1. It is evident that the existing entrepreneurs on average scored slightly positive on the set of entrepreneurial competencies that they possessed $(\mathrm{M}=3.77, \mathrm{SD}=0.46)$. Additionally, creative problemsolving, opportunity recognition and value creation were the strongest competencies possessed by the existing entrepreneurs. Interestingly, perseverance had the lowest composite score $(\mathrm{M}=3.618, \mathrm{SD}=0.635)$, and this could mean that the existing entrepreneurs relied heavily on their entrepreneurial experience and other competencies, such as creative problem-solving and so on, when engaging in recurring entrepreneurial action.

\section{Hypothesis tests}

\section{Test for hypothesis $1 \mathrm{a}$}

The stated hypothesis was directional and was tested at a 5\% level of significance, where $\alpha=0.05$. To test $\mathrm{H}_{1 \mathrm{a}}$ (there is a positive relationship between recurring entrepreneurial intention behaviours and recurring entrepreneurial action), the results of the Kolmogorov-Smirnov test indicated that there was not a normal distribution for recurring entrepreneurial intention behaviours $(p=0.0005)$, recurring entrepreneurial intention attitudes $(p=0.0005)$ and recurring entrepreneurial action $(p=0.033)$.

The assumption of linearity was tested using a scatter plot. Figure 4 confirms that there is a positive linear relationship between recurring entrepreneurial intention behaviours and recurring entrepreneurial action $\left(R^{2}=0.084\right)$.

Based on the results of these assumption tests, we made use of Spearman's rank-order correlation. Table 2 presents Spearman's rank-order correlation for recurring entrepreneurial intention behaviours and recurring entrepreneurial action.

The $p$-value for recurring entrepreneurial action $(p=0.059)$ indicates that the null hypothesis is not rejected. This suggests that there is no relationship between recurring entrepreneurial intention behaviours and recurring entrepreneurial action.
TABLE 1: The mean and standard deviation of each composite score for each competency.

\begin{tabular}{lccc}
\hline Construct & N & M & SD \\
\hline Competencies & 154 & 3.77 & 0.46 \\
Creative problem-solving & 154 & 3.94 & 0.61 \\
Opportunity recognition & 154 & 3.94 & 0.68 \\
Value creation & 153 & 3.93 & 0.66 \\
Self-efficacy & 153 & 3.68 & 0.80 \\
Resource leveraging & 154 & 3.64 & 0.60 \\
Networking & 153 & 3.62 & 0.77 \\
Perseverance & 154 & 3.61 & 0.63 \\
\hline
\end{tabular}

$N$, sample size (responses); $\mathrm{M}$, mean; $\mathrm{SD}$, standard deviation.

TABLE 2: Results of Spearman's rank-order correlation.

\begin{tabular}{llcc}
\hline Spearman's rho & Variable & $\begin{array}{c}\text { Recurring } \\
\text { entrepreneurial } \\
\text { intention behaviours }\end{array}$ & $\begin{array}{c}\text { Recurring } \\
\text { entrepreneurial } \\
\text { action }\end{array}$ \\
\hline $\begin{array}{llcc}\text { Recurring } \\
\text { entrepreneurial }\end{array}$ & Correlation coefficient & 1.000 & 0.183 \\
intention & $p$-value (one-tailed) & - & 0.059 \\
behaviours & $N$ & 152 & 74 \\
Recurring & Correlation coefficient & 0.183 & 1.000 \\
entrepreneurial & $p$-value (one-tailed) & 0.059 & - \\
action & $N$ & 74 & 74 \\
\hline
\end{tabular}

TABLE 3: Results of Spearman's rank-order correlation.

\begin{tabular}{llcc}
\hline Spearman's rho & Variable & $\begin{array}{c}\text { Recurring } \\
\text { entrepreneurial } \\
\text { intention attitudes }\end{array}$ & $\begin{array}{c}\text { Recurring } \\
\text { entrepreneurial } \\
\text { action }\end{array}$ \\
\hline $\begin{array}{llcc}\text { Recurring } \\
\text { entrepreneurial }\end{array}$ & Correlation coefficient & 1.000 & $0.328^{*}$ \\
intention attitudes & $p$-value (one-tailed) & - & 0.002 \\
& $N$ & 150 & 73 \\
Recurring & Correlation coefficient & $0.328^{*}$ & 1.000 \\
entrepreneurial & $p$-value (one-tailed) & 0.002 & - \\
action & $N$ & 73 & 74 \\
\hline
\end{tabular}

*, Correlation is significant at the 0.01 level (one-tailed).

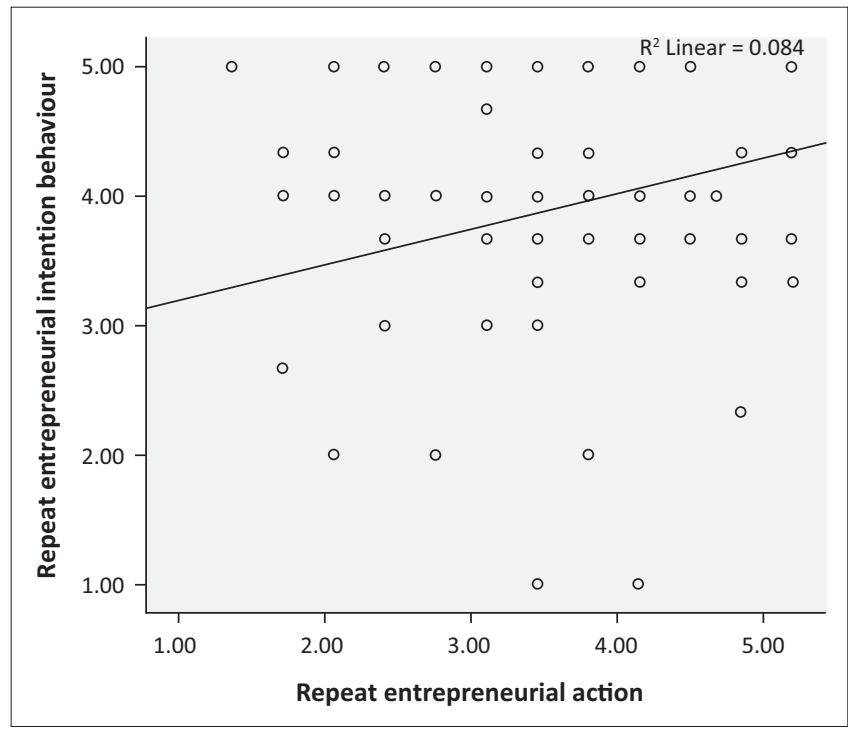

FIGURE 4: Scatter plot showing the relationship between recurring entrepreneurial intention behaviours and recurring entrepreneurial action.

\section{Tests for hypothesis $\mathbf{1 b}$}

To test $\mathrm{H}_{1 \mathrm{~b}}$ (there is a positive relationship between recurring entrepreneurial intention attitudes and recurring entrepreneurial action), Figure 5 indicates that there is a positive linear relationship between recurring entrepreneurial intention attitudes and recurring entrepreneurial action $\left(R^{2}=0.109\right)$. 


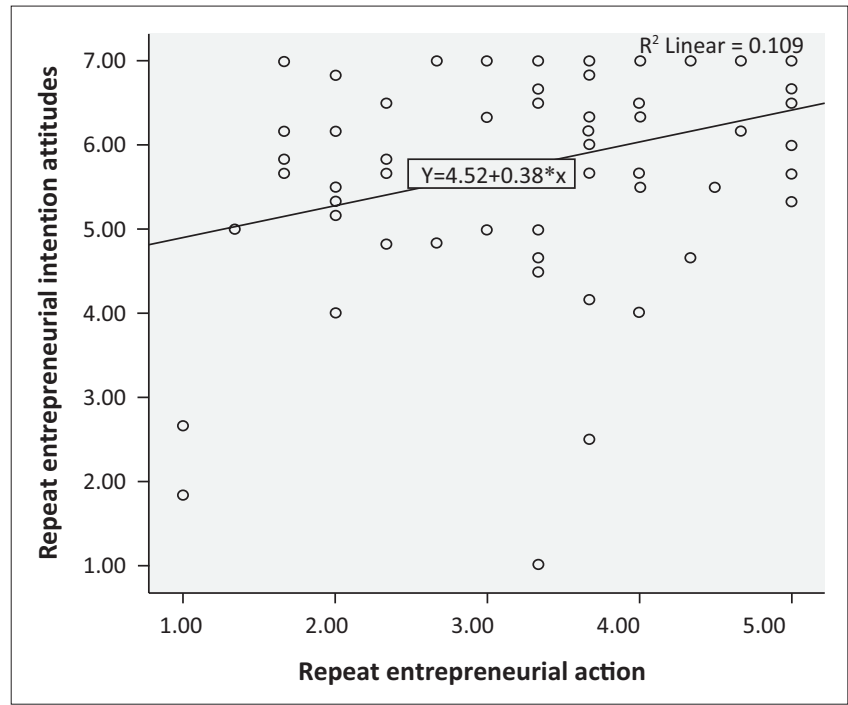

FIGURE 5: Scatter plot showing the relationship between recurring entrepreneurial intention attitudes and recurring entrepreneurial action.

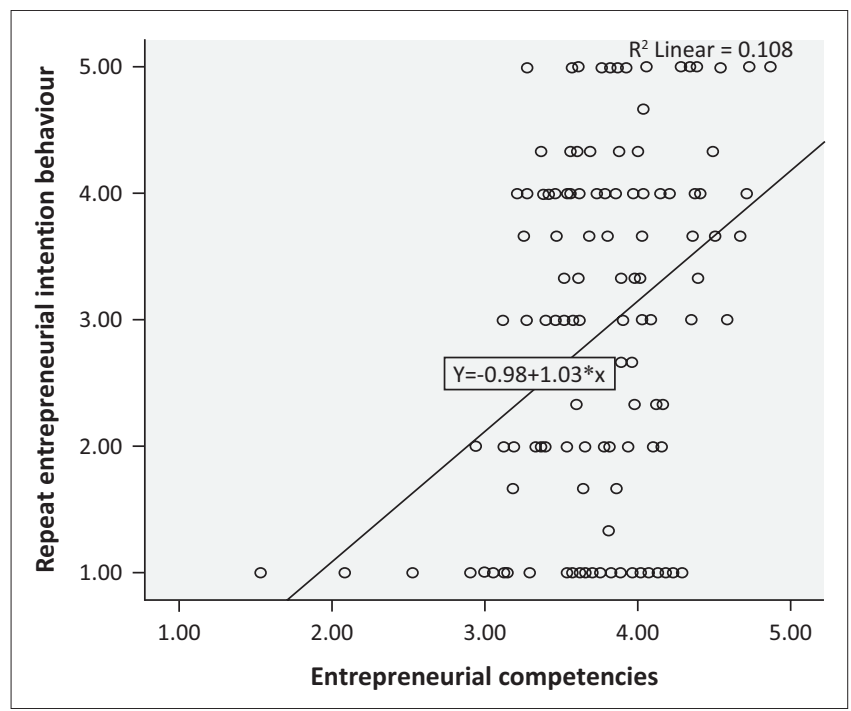

FIGURE 6: Scatter plot showing the relationship between recurring entrepreneurial intention behaviours and entrepreneurial competencies.

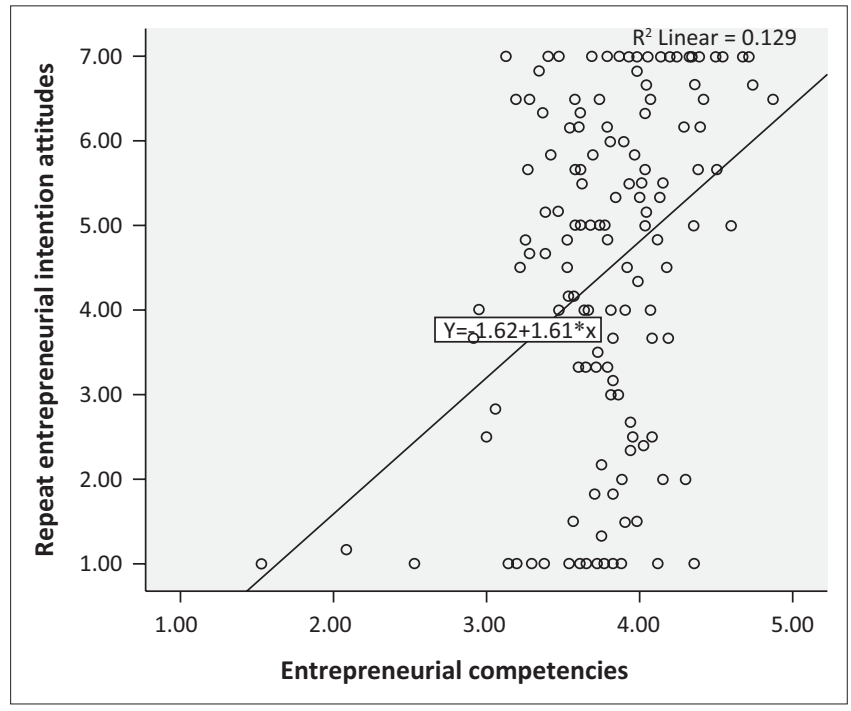

FIGURE 7: Scatter plot showing the relationship between recurring entrepreneurial intention attitudes and entrepreneurial competencies.
Table 3 shows the results for the Spearman's rank-order correlation (Spearman's rho) for recurring entrepreneurial intention attitudes and recurring entrepreneurial action.

The $p$-value for recurring entrepreneurial action $(p=0.002)$ indicates that the null hypothesis is rejected. This suggests that there is a positive relationship between recurring entrepreneurial intention attitudes and recurring entrepreneurial action.

\section{Test for hypothesis $2 \mathrm{a}$}

To test $\mathrm{H}_{2 \mathrm{a}}$ (there is a positive relationship between a set of entrepreneurial competencies and recurring entrepreneurial intention behaviours), a scatter plot is constructed in Figure 6. The figure confirms that there is a positive linear relationship between recurring entrepreneurial intention behaviours and entrepreneurial competencies $\left(R^{2}=0.108\right)$.

Table 4 shows the results of the Spearman's rank-order correlation for recurring entrepreneurial intention behaviours and entrepreneurial competencies.

\section{Tests for hypothesis $\mathbf{2 b}$}

To test $\mathrm{H}_{2 \mathrm{~b}}$ (there is a positive relationship between a set of entrepreneurial competencies and recurring entrepreneurial intention attitudes), the scatter plot in Figure 7 confirms that there is a positive linear relationship between recurring entrepreneurial intention attitudes and entrepreneurial competencies $\left(R^{2}=0.129\right)$.

Table 5 indicates the results for the Spearman's rank-order correlation for recurring entrepreneurial intention attitudes and entrepreneurial competencies.

TABLE 4: Results of Spearman's rank-order correlation.

\begin{tabular}{llcc}
\hline Spearman's rho & Variable & $\begin{array}{c}\text { Recurring } \\
\text { entrepreneurial } \\
\text { intention behaviours }\end{array}$ & $\begin{array}{c}\text { Entrepreneurial } \\
\text { competencies }\end{array}$ \\
\hline $\begin{array}{l}\text { Recurring } \\
\text { entrepreneurial }\end{array}$ & Correlation coefficient & 1.000 & $0.257^{*}$ \\
intention & $p$-value (one-tailed) & - & 0.001 \\
behaviours & $N$ & 152 & 152 \\
Entrepreneurial & Correlation coefficient & $0.257^{*}$ & 1.000 \\
competencies & $p$-value (one-tailed) & 0.001 & - \\
& $N$ & 152 & 154 \\
\hline
\end{tabular}

Note: The $p$-value for recurring entrepreneurial action $(p=0.001)$ indicates that there is a positive relationship between recurring entrepreneurial intention behaviours and entrepreneurial competencies.

*, Correlation is significant at the 0.01 level (one-tailed).

TABLE 5: Results of Spearman's rank-order correlation.

\begin{tabular}{llcc}
\hline Spearman's rho & Variable & $\begin{array}{c}\text { Recurring } \\
\text { entrepreneurial } \\
\text { intention attitudes }\end{array}$ & $\begin{array}{c}\text { Entrepreneurial } \\
\text { competencies }\end{array}$ \\
\hline Recurring & Correlation coefficient & 1.000 & $0.319^{*}$ \\
entrepreneurial & $p$-value (one-tailed) & - & 0.000 \\
intention & $N$ & 150 & 150 \\
attitudes & Correlation coefficient & $0.319^{*}$ & 1.000 \\
Entrepreneurial & 0.000 & - \\
competencies & $p$-value (one-tailed) & 150 & 154 \\
& $N$ & & \\
\hline
\end{tabular}

*, Correlation is significant at the 0.01 level (one-tailed). 
The $p$-value for entrepreneurial competencies $(p=0.001)$ indicates that there is a positive relationship between recurring entrepreneurial intention attitudes and entrepreneurial competencies.

\section{Hypothesis 3}

To test $\mathrm{H}_{3}$ (there is a positive relationship between entrepreneurial competencies and recurring entrepreneurial action), the scatter plot in Figure 8 indicates that there is a positive linear relationship between recurring entrepreneurial action and entrepreneurial competencies $\left(R^{2}=0.146\right)$.

The recurring entrepreneurial action and competencies were measured at an interval level where the appropriate parametric test would be Pearson's product-moment correlation. If the assumptions of this test cannot be satisfied, Spearman's rank-order correlation would be conducted as a non-parametric alternative (Kotzé 2012:34).

Table 6 shows the results of the Pearson's product-moment correlation for recurring entrepreneurial action and entrepreneurial competencies.

The $p$-value for entrepreneurial competencies $(p=0.000)$ indicates that there is a positive relationship between recurring entrepreneurial action and entrepreneurial competencies.

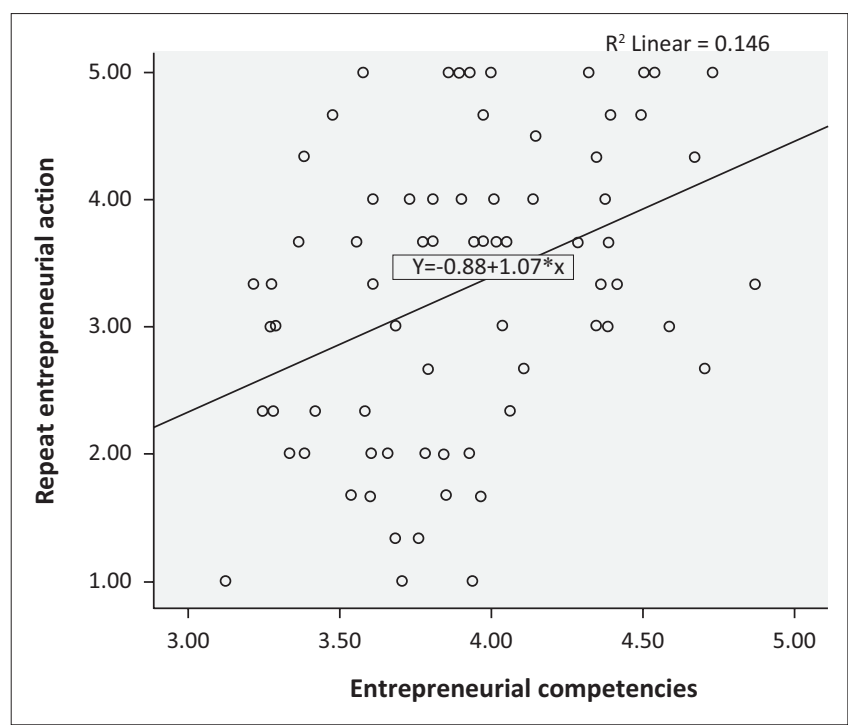

FIGURE 8: Scatter plot showing the relationship between recurring entrepreneurial action and entrepreneurial competencies.

\begin{tabular}{llcc} 
TABLE 6: Results of Pearson's product-moment correlation. & \\
\hline Spearman's rho & Variable & $\begin{array}{c}\text { Recurring } \\
\text { entrepreneurial } \\
\text { action }\end{array}$ & $\begin{array}{c}\text { Entrepreneurial } \\
\text { competencies }\end{array}$ \\
\hline Recurring & Pearson correlation & 1 & $0.383^{*}$ \\
entrepreneurial & $p$-value (one-tailed) & - & 0.000 \\
action & $N$ & 74 & 74 \\
Entrepreneurial & Pearson correlation & $0.383^{*}$ & 1 \\
competencies & $p$-value (one-tailed) & 0.000 & - \\
& $N$ & 74 & 154 \\
\hline
\end{tabular}

*, Correlation is significant at the 0.01 level (one-tailed).

\section{Discussion of the findings}

The findings indicate that when measuring entrepreneurial intention, recurring entrepreneurial intention behaviours do not have a statistically significant relationship with recurring entrepreneurial action.

Therefore we cannot accept $\mathrm{H}_{1 \mathrm{a}}$ (there is a positive relationship between recurring entrepreneurial intention behaviours and recurring entrepreneurial action). This finding is unexpected and contrasts with a certain number of the TPB models found in the literature, which indicate that behavioural intention is a result of attitudes around certain behaviours, in this case starting a business (Ajzen 1991:181; Boyd \& Vozikis 1994:64; Krueger et al. 2000:414). Yet it confirms the overall notion by other scholars such as Fayolle and Degeorge (2006:78), Nabi et al. (2013:2) and Smith and Beasley (2011:725) that intentional behaviours do not necessarily lead to action, even for existing entrepreneurs. Yet recurring entrepreneurial intention attitudes do have a statistically significant positive relationship with recurring entrepreneurial action, and we can accept $\mathrm{H}_{1 \mathrm{~b}}$ (there is a positive relationship between recurring entrepreneurial intention attitudes and recurring entrepreneurial action). The average for recurring entrepreneurial intention behaviours was slightly negative $(\mathrm{M}=2.91$, where the neutral value was 3$)$, compared to the attitudes, which were overall positive $(\mathrm{M}=4.46$, where the neutral value was 4 ). Thus, even though their attitudes may indicate that they intend to start another business, their actual behaviour related to starting the business is not as confounding. As Anokhin et al. (2008:139) pointed out, if an entrepreneur encompasses a certain number of competencies, he or she is more likely to be successful in their first venture. Hence, they may still have positive attitudes (higher perceived desirability) with regard to starting another business, but their current situation does not necessarily require them to have real behavioural intention (lower perceived feasibility) in this regard and consequently negates a need for the entrepreneurs to take further action (RodríguezCohard \& Rueda-Cantuche 2011:198-199).

In terms of entrepreneurial competencies, there is a statistically significant positive relationship towards the behaviours and attitudes that entrepreneurs have related to recurring entrepreneurial intention. We can, therefore, accept both $\mathrm{H}_{2 \mathrm{a}}$ (there is a positive relationship between a set of entrepreneurial competencies and recurring entrepreneurial intention behaviours) and $\mathrm{H}_{2 b}$ (there is a positive relationship between a set of entrepreneurial competencies and recurring entrepreneurial intention attitudes). Because of the experience that entrepreneurs have gained from their previous entrepreneurial ventures, entrepreneurs have potentially seen development of their competencies (Chell 2008:157). The success or failure of a previous business can also encourage recurring intention from the entrepreneur, depending on their enjoyment of success or desire to rectify a failure (Bandura 1977:194; Pretorius \& Le Roux 2011:1-13). It is potentially these experiences from previous business ventures 
that support the result that competencies and recurring entrepreneurial intention have a positive relationship.

Finally, the findings also indicate that there is a positive relationship between recurring entrepreneurial action and entrepreneurial competencies, and we accept $\mathrm{H}_{3}$. As Presutti et al. (2008:4) point out, the competencies that were learnt from previous business experience are vital for entrepreneurs to be successful in taking future action. The close association of growth and performance, which leads to economic development, can be attributed to entrepreneurial competencies and the various drivers that make up these entrepreneurial competencies (Mitchelmore \& Rowley 2010:4). Entrepreneurial competencies allow the emergence of a new venture by providing the ability to construct a set of resources that would be necessary to build a venture (Danneels 2002:1095; Rasmussen, Mosey \& Wright 2014:6). Having a competency such as self-efficacy allows entrepreneurs to persevere with an activity that nonentrepreneurs may struggle to pursue (Bandura 2012:14). Further, Baron (2004:227) states that recurring entrepreneurs are often able to easily recognise opportunities that may at first seem like unrelated opportunities, but recurring entrepreneurs are able to convert these opportunities into valuable components of a business. From the preceding findings it is evident that entrepreneurial competencies play a significant role in the intention-action relationship.

\section{Conclusion}

The main purpose of this article was to investigate that relationship that entrepreneurial competencies have with recurring entrepreneurial intention (attitudes and behaviours) and recurring entrepreneurial action.

Although other studies have focused on each of these constructs independently, as far as could be determined, no research had been conducted that investigated the relationship between all three of these constructs, especially recurring intention and action. This is important, as recurring entrepreneurs are a significant part in understanding the process that entrepreneurs undertake (Scott \& Rosa 1996:86).

Furthermore, this article found that entrepreneurial competencies play a significant role in the recurring entrepreneurial intention and action that existing entrepreneurs face when looking at starting another business venture. The findings of this article advance that it is crucial to include the seven entrepreneurial competencies (opportunity recognition, perseverance, problem-solving, resource leveraging, value creation, networking and self-efficacy) in the relationship between recurring intention and action, as they can provide possible improvements to the practice of entrepreneurship and to the advancement of entrepreneurial education (Morris et al. 2013b:353).

The first contribution of this article is towards the entrepreneurial intention-action literature in the sense that recurring entrepreneurial intention (attitudes and behaviours) and recurring entrepreneurial action can be measured on existing entrepreneurs. Previous literature indicated that there is a gap between intention and action and that entrepreneurial intention does not necessarily lead to action. However, previous intention research was conducted on student, potential, novice and non-entrepreneurs such as managers. It is our contention that we might have neglected some samples when measuring the intentionaction relationships.

By focusing on existing entrepreneurs, we were able to learn from a group that had already taken the leap towards intent and action or had taken that step again. We furthermore measured a set of competencies with recurring intention and action and found positive relationships between these constructs. By understanding which competencies existing entrepreneurs rely on the most when engaging in recurring action, educators and policymakers can ensure that these competencies are present and developed in start-up training and support programmes.

The next contribution of this article is towards the construct of entrepreneurial intention. By measuring both entrepreneurial intention attitudes, as well as entrepreneurial intention behaviours in this article, we were able to test separately the individual relationships of recurring entrepreneurial intention attitudes and recurring entrepreneurial intention behaviours with recurring action. This article's findings revealed that recurring entrepreneurial intention behaviours do not have a positive relationship with recurring action, and we confirmed that even for existing entrepreneurs intentional behaviours do not necessarily lead to action.

Entrepreneurial competencies might be the missing link between these constructs, as a positive relationship was found between both entrepreneurial intention attitudes, behaviours and competencies as well as entrepreneurial action and competencies. Existing entrepreneurs with a recurring intention must focus on their commitment to taking action. Although their attitudes may indicate that they have the intention to start a business, their behavioural intention to start another business is often not as strong. This can lead to a lack of focus for an entrepreneur, possibly on their current business, as they have their focus elsewhere. This can also apply to their potential new business, as they are not necessarily fully committed to making it happen.

As Alsos et al. (2006:47) point out, this 'value creation' can often be an issue for entrepreneurs, because by attempting to create value through numerous ventures, focus can be lost on their initial core business.

This does not suggest that entrepreneurs cannot have intentions for new businesses; it rather points to the fact that they must ensure that attention is given to all ventures that are undertaken. Thirdly, this study investigated the entrepreneurial competencies of existing entrepreneurs in a developing country context. Most of the research on entrepreneurial 
competencies has been conducted in developed countries, and we answered the call for more entrepreneurship research in an African context. Other developing countries with low entrepreneurial activity levels can learn from this article and also focus on existing entrepreneurs and encourage them to engage in recurring entrepreneurial action. At the same time, the competencies identified that were the most relied on by existing entrepreneurs could also be developed and enhanced in developed countries. Finally, students, aspiring and novice entrepreneurs can use the finding in this article that the entrepreneurial competencies such as creative problemsolving, opportunity recognition and value creation should be developed if they wish to engage in entrepreneurial action. Developing these competencies may provide increased performance in their current situation, as well as for the expansion of a new venture.

\section{Limitations}

The major limitation of this study was the sampling method used. As only existing entrepreneurs were included in the measurement, it means that the results of this study cannot be generalised to the entire population (Cooper \& Schindler 2014:358). There is also low external validity for the research when non-probability sampling is used (Creswell \& Clark 2011:101).

This study was also limited by the total number of respondents. This could be because of the data collection method used, as Internet surveys have very low response rates (Kotzé 2017). To counter this, a larger volume of e-mails should have been distributed to account for these anticipated low response and completion rates.

The final limitation that could have occurred is response bias, and specifically unconscious misrepresentation. The respondents taking part in the study wanted to provide the truth, but the information that they provided may not have been completely reflective of the actual truth (University of Pretoria 2016:2). The respondents may have believed they were answering the questions correctly but may have overor underestimated their competencies and intentions compared to their actual representation.

However, this is a common problem in scientific research of this nature.

\section{Recommendations for future research}

The first recommendation for future research could be to draw a comparison of competencies of existing entrepreneurs and those who are nascent entrepreneurs, or people who have no intention at all to become entrepreneurs. The differences in competency levels could further assist to determine the competencies that potential entrepreneurs will need to develop to become serial or recurring entrepreneurs. As we found a positive relationship between recurring entrepreneurial intention attitudes and recurring action but not between recurring entrepreneurial intention behaviours and recurring action, this study suggests that future studies on entrepreneurial intention should measure this construct by testing attitudes and behaviours separately. Investigating the possibility of introducing demographic variables such as age, gender and level of education as mediators and moderators in the relationship between entrepreneurial intention behaviours and action could enhance this relationship.

Another potential recommendation for future research could be comparing the competencies of entrepreneurs depending on the number of businesses that they have owned. As Anokhin et al. (2008:138) point out, if the entrepreneur has effective competencies, specifically problem-solving, during their first venture, it is unlikely that they will engage in recurring entrepreneurship because of their first venture having a higher likelihood of success. Determining whether those entrepreneurs who have started one business have higher levels of the individual entrepreneurial competencies compared to those who have started multiple businesses could be an interesting area of future research. Furthermore, the results of this study could be compared to research conducted in developed countries to study the recurring intention-action relationship of existing entrepreneurs. It would also be interesting to determine whether the competencies that entrepreneurs in developed countries rely on in this recurring relationship differ from the competencies found in this article for entrepreneurs in a developing country.

The methodology and research design can also be improved in future research. Firstly, depending on the target group, sampling could be done in a different manner and attempting to increase the sample size. If a research design is followed based on the previous recommendations, quota sampling could potentially be used as a sampling method. This would allow the researchers to select the correct number of grouping respondents in their study. Furthermore, although Internet surveys can provide volume, the response rates will still be low, so alternative data collection methods should be considered. Conducting self-administered questionnaires may be a better solution for future researchers to reach their sample size. Looking at the data collection instrument, it might be a good idea to make it shorter. To do this, future researchers could be more selective in the competencies that they choose to research or could reduce the number of items under each competency. This may assist in achieving a greater response rate.

\section{Acknowledgements Competing interests}

The authors have declared that no competing interests exist.

\section{Author's contributions}

T.C. and M.V. were BCom (Hons) students and completed this research article as part of their studies. They collected the 
data and compiled the initial literature review. M.B. was their supervisor and completed and rewrote the article to get it into a publishable format.

\section{References}

Ahmad, N.H., 2007, A cross cultural study of entrepreneurial competencies and entrepreneurial success in SMEs in Australia and Malaysia, pp. 1-323, University of Adelaide, Australia.

Ajzen, I., 1991, 'The theory of planned behavior', Organizational Behavior and Human Decision Processes 50(2), 179-211. https://doi.org/10.1016/07495978(91)90020-T

Al-Debei, M.M., Al-Lozi, E. \& Papazafeiropoulou, A., 2013, 'Why people keep coming back to Facebook: Explaining and predicting continuance participation from an extended theory of planned behaviours perspective', Decision Support Systems 55(1), 43-54. https://doi.org/10.1016/j.dss.2012.12.032

Alsos, G.A., Kolvereid, L. \& Isaksen, E.J., 2006, 'New business early performance: Differences between firms started by novice, serial and portfolio entrepreneurs', Managing Complexity and Change in SMEs: Frontiers in European Research 35-49.

Anokhin, S., Grichnik, D. \& Hisrich, R.D., 2008, 'The journey from novice to serial entrepreneurship in China and Germany: Are the drivers the same?', Managing Global Transitions 6(2), 117-142.

Bagozzi, R.P., Baumgartner, J. \& Yi, Y., 1989, 'An investigation into the role of intentions as mediators of the attitude-behavior relationship', Journal of Economic Psychology 10(1), 35-62. https://doi.org/10.1016/0167-4870(89)90056-1

Bandura, A., 1977, 'Self-efficacy: Toward a unifying theory of behavioral change', Psychological Review 84(2), 191-251. https://doi.org/10.1037/0033-295X. 84.2.191

Bandura, A., 1991, 'Social cognitive theory of self-regulation', Organizational Behavior and Human Decision Processes 50(2), 248-287. https://doi.org/10.1016/07495978(91)90022-L

Bandura, A., 2012, 'On the functional properties of perceived self-efficacy revisited', Journal of Management 38(1), 9-44. https://doi.org/10.1177/0149206311410606

Baron, R.A., 2004, 'The cognitive perspective: A valuable tool for answering entrepreneurship's basic "why" questions', Journal of Business Venturing 19(2), 221-239. https://doi.org/10.1016/S0883-9026(03)00008-9

Baron, R.A., 2007, 'Behavioral and cognitive factors in entrepreneurship: Entrepreneurs as the active element in new venture creation', Strategic Entrepreneurship Journal 1(1-2), 167-182. https://doi.org/10.1002/sej.12

Boyatzis, R., 2008, 'Competencies in the 21st century', Journal of Management Development 27(1), 5-12. https://doi.org/10.1108/02621710810840730

Boyatzis, R.E., 1982, The competent manager: A model for effective performance, John Wiley, Hoboken, NJ.

Boyd, N.G. \& Vozikis, G.S., 1994, 'The influence of self-efficacy on the development of entrepreneurial intentions and actions', Entrepreneurship Theory and Practice 18, 63-63. https://doi.org/10.1177/104225879401800404

Brandstätter, H., 2011, 'Personality aspects of entrepreneurship: A look at five metaanalyses', Personality and Individual Differences 51(3), 222-230. https://doi. org/10.1016/j.paid.2010.07.007

Brinckmann, J. \& Kim, S.M., 2015, 'Why we plan: The impact of nascent entrepreneurs' cognitive characteristics and human capital on business planning', Strategic Entrepreneurship Journal 9(2), 153-166. https://doi.org/10.1002/sej.1197

Carland, J.C., Carland, J.W. \& Stewart, W.H., 2000, 'The indefatigable entrepreneur: A study of the dispositions of multiple venture founders', Journal of Business and Entrepreneurship 12(1), 1-18.

Chell, E., 2008, The entrepreneurial personality: A social construction, Routledge, Hove.

Choo, S. \& Wong, M., 2006, 'Entrepreneurial intention: Triggers and barriers to new venture creations in Singapore', Singapore Management Review 28(2), 47.

Cooper, D.R. \& Schindler, P.S., 2014, Business research methods, 12th edn., McGrawHill, Singapore.

Creswell, J. \& Clark, V.P., 2011, Collecting data in mixed methods research. Designing and conducting mixed methods research, pp. 171-202, Sage Publications, Thousand Oaks, CA.

Danneels, E., 2002, 'The dynamics of product innovation and firm competences', Strategic Management Journal 23(12), 1095-1121. https://doi.org/10.1002/ smj. 275

Douglas, E.J. \& Shepherd, D.A., 2002, 'Self-employment as a career choice: Attitudes, entrepreneurial intentions, and utility maximization', Entrepreneurship Theory and Practice 26(3), 81-90. https://doi.org/10.1177/104225870202600305

Duckworth, A.L. \& Quinn, P.D., 2009, 'Development and validation of the short grit scale (grit-s)', Journal of 'Personality Assessment 91(2), 166-174. https://doi. org/10.1080/00223890802634290

Dyer, J.H., Gregersen, H.B. \& Christensen, C., 2008, 'Entrepreneur behaviors, opportunity recognition, and the origins of innovative ventures', Strategic Entrepreneurship Journal 2(4), 317-338. https://doi.org/10.1002/sej.59

Eroglu, O. \& Piçak, M., 2011, 'Entrepreneurship, national culture and Turkey', International Journal of Business and Social Science 2(16), 146-151.
Fayolle, A. \& Degeorge, J.M. (eds.), 2006, 'Attitudes, intentions, and behaviours: New approaches to evaluating entrepreneurship education', International Entrepreneurship Education: Issues and Newness, pp. 74-89, Edward Elgar Entrepreneurship Education: Issues and Newness, pp. 74-89, Edward Elgar
Publishing Limited, Cheltenham. https://doi.org/10.4337/9781847201652.00011

Forret, M.L. \& Dougherty, T.W., 2001, 'Correlates of networking behavior for managerial and professional employees', Group \& Organization Management 26(3), 283-311. https://doi.org/10.1177/1059601101263004

Francis, J., Eccles, M.P., Johnston, M., Walker, A., Grimshaw, J., Foy, R. et al., 2004 Constructing questionnaires based on the theory of planned behaviours: A manual for health services researchers, viewed 04 March 2017, from http://openaccess. city.ac.uk/1735/1/TPB\%20Manual\%20FINAL\%20May2004.pdf.

Frese, M., 2009, 'Towards a psychology of entrepreneurship: An action theory perspective', Foundations and Trends in Entrepreneurship 5(6), 437-496. https:// doi.org/10.1561/0300000028

Frese, M. \& Zapf, D., 1994, 'Action as the core of work psychology: A German approach', in H.C. Triandis, M.D. Dunnette \& L.M. Hough (eds.), Handbook of industrial and organizational psychology, 2nd edn., Consulting Psychologists Press, Palo Alto, CA.

Gartner, W.B., 1985, 'A conceptual framework for describing the phenomenon of new venture creation', Academy of Management Review 10(4), 696-706. https://doi. org/10.5465/amr.1985.4279094

George, G., Corbishley, C., Khayesi, J.N., Haas, M.R. \& Tihanyi, L., 2016, 'Bringing Africa in: Promising directions for management research', Academy of Management Journal 59(2), 377-393. https://doi.org/10.5465/amj.2016.4002

Guerrero, M. \& Peña-Legazkue, I., 2018, 'Renascence after post-mortem: The choice of accelerated recurring entrepreneurship', Small Business Economics, pp. 1-19.

Gielnik, M.M., Frese, M., Kahara-Kawuki, A., Wasswa Katono, I., Kyejjusa, S., Ngoma, M. et al., 2015, 'Action and action-regulation in entrepreneurship: Evaluating a student training for promoting entrepreneurship', Academy of Management Learning \& Education 14(1), 69-94. https://doi.org/10.5465/amle.2012.0107

Gollwitzer, P.M., 1990, 'Action phases and mind-sets', Handbook of Motivation and Cognition: Foundations of Social Behavior 2, 53-92.

Hayward, M.L., Forster, W.R., Sarasvathy, S.D. \& Fredrickson, B.L., 2010, 'Beyond hubris: How highly confident entrepreneurs rebound to venture again', Journal of Business Venturing 25(6), 569-578. https://doi.org/10.1016/j.jbusvent.2009.03.002

Herrington, M., Kew, P. \& Mwanga, A., 2017, Global entrepreneurship monitor (GEM): Can small businesses survive in South Africa?, viewed 21 February 2018, from https:// www.researchgate.net/profile/Jacqui_Kew/publication/317566088_GEM_South Africa_2009_Tracking_Entrepreneurship/links/593ff940aca272876dc422d0/GEMSouth-Africa-2009-Tracking-Entrepreneurship.pdf.

Hmieleski, K.M. \& Corbett, A.C., 2006, 'Proclivity for improvisation as a predictor of entrepreneurial intentions', Journal of Small Business Management 44(1), 45-63. https://doi.org/10.1111/j.1540-627X.2006.00153.x

Hsu, D.K., 2011, Toward a theory of serial entrepreneurship: Decomposing entrepreneurial experience, pp. 73-76, Syracuse University, Syracuse, New York.

Hsu, D.K., Wiklund, J. \& Cotton, R.D., 2017, 'Success, failure, and entrepreneurial reentry: An experimental assessment of the veracity of self-efficacy and prospect theory', Entrepreneurship Theory and Practice 41(1), 19-47. https://doi.org/ 10.1111/etap.12166

Jayawarna, D., Rouse, J. \& Macpherson, A., 2014, 'Life course pathways to business start-up', Entrepreneurship \& Regional Development 26(3-4), 282-312. https:// doi.org/10.1080/08985626.2014.901420

Kautonen, T., Gelderen, M. \& Fink, M., 2015, 'Robustness of the theory of planned behavior in predicting entrepreneurial intentions and actions', Entrepreneurship Theory and Practice 39(3), 655-674. https://doi.org/10.1111/etap.12056

Kellermanns, F.W., Eddleston, K.A., Barnett, T. \& Pearson, A., 2008, 'An exploratory study of family member characteristics and involvement: Effects on entrepreneurial behavior in the family firm', Family Business Review 21(1), 1-14. https://doi. org/10.1111/j.1741-6248.2007.00107.x

Kolvereid, L. \& Isaksen, E., 2006, 'New business start-up and subsequent entry into self-employment', Journal of Business Venturing 21(6), 866-885. https://doi. self-employment', Journal of Business
org/10.1016/j.jbusvent.2005.06.008

Kotzé, T.G., 2012, SPSS workshop 2, Department of Marketing Management, University of Pretoria, Pretoria, viewed 07 June 2017, from https://clickup.up.ac.za.

Kotzé, T.G., 2017, Contact session 8 for NME 704: Research methodology, Slides presented to the NME 704 class on 2017-04-03, Department of Business Management, University of Pretoria, Pretoria, viewed 17 June 2017, from https:// clickup.up.ac.za.

Krueger, N.F., Reilly, M.D. \& Carsrud, A.L., 2000, 'Competing models of entrepreneurial intentions', Journal of Business Venturing 15(5-6), 411-432. https://doi. org/10.1016/S0883-9026(98)00033-0

Lee, S.M. \& Lee, B., 2015, 'Entrepreneur characteristics and the success of venture exit: An analysis of single-founder start-ups in the US', International Entrepreneurship and Management Journal 11(4), 891-905. https://doi.org/10.1007/s11365-0140324-5

Lichtenstein, B.B., Carter, N.M., Dooley, K.J. \& Gartner, W.B., 2007, 'Complexity dynamics of nascent entrepreneurship', Journal of Business Venturing 22(2), 236-261. https://doi.org/10.1016/j.jbusvent.2006.06.001

Liñán, F., Rodríguez-Cohard, J.C. \& Rueda-Cantuche, J.M., 2011, Factors affecting entrepreneurial intention levels: A role for education', International Entrepreneurship and Management Journal 7(2), 195-218. https://doi.org/ 10.1007/s11365-010-0154-z

MacMillan, I.C., 1986, 'Executive forum: To really learn about entrepreneurship, let's study habitual entrepreneurs', Journal of Business Venturing 1(3), 241-243. https://doi.org/10.1017/S1744137413000386 
McMullen, J.S., 2015, 'Entrepreneurial judgment as empathic accuracy: A sequential decision-making approach to entrepreneurial action' Journal of Institutional Economics 11(3), 651-681. https://doi.org/10.1017/S1744137413000386

Miralles, F., Giones, F. \& Riverola, C., 2016, 'Evaluating the impact of prior experience in entrepreneurial intention', International Entrepreneurship and Management Journal 12(3), 791-813. https://doi.org/10.1007/s11365-015-0365-4

Mischel, W., 1973, 'Toward a cognitive social learning reconceptualization of personality', Psychological Review 80(4), 252-283. https://doi.org/10.1037/ h0035002

Mitchell, R.K., Smith, B., Seawright, K.W. \& Morse, E.A., 2000, 'Cross-cultural cognitions and the venture creation decision', Academy of Management Journal 43(5), 974-993.

Mitchelmore, S. \& Rowley, J., 2010, 'Entrepreneurial competencies: A literature review and development agenda', International Journal of Entrepreneurial Behavior \& Research 16(2), 92-111. https://doi.org/10.1108/13552551011026995

Morris, M.H., Kuratko, D.F. \& Cornwall, J.R., 2013a, Entrepreneurship programs and the modern university, Edward Elgar Publishing, Cheltenham. https://doi. org/10.4337/9781782544630

Morris, M.H., Webb, J.W., Fu, J. \& Singhal, S., 2013b, 'A competency-based perspective on entrepreneurship education: Conceptual and empirical insights', Journal of on entrepreneurship education: Conceptual
Small Business Management 51(3), 352-369.

Nabi, G., Walmsley, A. \& Holden, R., 2015, 'Pushed or pulled? Exploring the factors underpinning graduate start-ups and non-start-ups', Journal of Education and Work 28(5), 481-506. https://doi.org/10.1080/13639080.2013.805189

Politis, D., Winborg, J. \& Dahlstrand, A.L., 2012, 'Exploring the resource logic of student entrepreneurs', International Small Business Journal 30(6), 659-683. https://doi.org/10.1080/13639080.2013.805189

Presutti, M., Onetti, A. \& Odorici, V., 2008, Serial entrepreneurship and born-globa new ventures: A case study, viewed 09 June 2017, from https://ssrn.com/ abstract $=1145202$

Pretorius, M. \& Le Roux, I., 2011, 'Successive failure, recurring entrepreneurship and no learning: A case study: Original research', SA Journal of Human Resource Management 9(1), 1-13. https://doi.org/10.4102/sajhrm.v9i1.236

Rasmussen, E., Mosey, S. \& Wright, M., 2011, 'The evolution of entrepreneurial competencies: A longitudinal study of university spin-off venture emergence' Journal of Management Studies 48(6), 1314-1345. https://doi.org/10.1111/ j.1467-6486.2010.00995.x

Robinson, P.B., Stimpson, D.V., Huefner, J.C. \& Hunt, H.K., 1991, 'An attitude approach to the prediction of entrepreneurship', Entrepreneurship Theory and Practice 15(4), 13-31. https://doi.org/10.1177/104225879101500405

Rodríguez-Cohard, J.C. \& Rueda-Cantuche, J.M., 2011, 'Factors affecting entrepreneurial intention levels: A role for education', The International Entrepreneurship and Management Journal 7(2), 195-218. https://doi.org/10.1007/ Entrepreneurship and

Schlaegel, C. \& Koenig, M., 2014, 'Determinants of entrepreneurial intent: A metaanalytic test and integration of competing models', Entrepreneurship Theory and Practice 38(2), 291-332. https://doi.org/10.1111/etap.12087

Scott, M. \& Rosa, P., 1996, 'Opinion: Has firm level analysis reached its limits? Time for a rethink?', International Small Business Journal 14(4), 81-89. https://doi. org/10.1177/0266242696144006

Segal, G., Borgia, D. \& Schoenfeld, J., 2005, 'The motivation to become an entrepreneur', International Journal of Entrepreneurial Behavior \& Research 11(1), 42-57. https://doi.org/10.1108/13552550510580834

Shane, S., Locke, E.A. \& Collins, C.J., 2003, 'Entrepreneurial motivation', Human Resource Management Review 13(2), 257-279. https://doi.org/10.1016/S10534822(03)00017-2

Shapero, A. \& Sokol, L., 1982, 'Social dimensions of entrepreneurship', in C.A. Kent, D.L. Sexton \& K.H. Vesper (eds.), Encyclopedia of entrepreneurship, Prentice-Hall, Englewood Cliffs, NJ.
Simmons, S.A., Carr, J.C., Hsu, D.K. \& Shu, C., 2016, 'The regulatory fit of serial entrepreneurship intentions', Applied Psychology 65(3), 605-627. https://doi.org/ 10.1111/apps.12070

Smeltzer, L.R., Van Hook, B.L. \& Hutt, R.W., 1991, 'Analysis of the use of advisors as information sources in venture startups', Journal of Small Business Management 29(3), 10.

Smith, K. \& Beasley, M., 2011, 'Graduate entrepreneurs: Intentions, barriers and solutions', Education and Training 53(8/9), 722-740. https://doi.org/10.1108/ 00400911111185044

Spivack, A.J., McKelvie, A. \& Haynie, J.M., 2014, 'Habitual entrepreneurs: Possible cases of entrepreneurship addiction?', Journal of Business Venturing 29(5), 651-667. https://doi.org/10.1016/j.jbusvent.2013.11.002

Stam, E. \& Schutjens, V., 2006, 'Starting anew: Entrepreneurial intentions and realizations subsequent to business closure', Erasmus Research Institute of Management, pp. 1-23.

Tang, J., Kacmar, K.M. \& Busenitz, L., 2012, 'Entrepreneurial alertness in the pursuit of new opportunities', Journal of Business Venturing 27(1), 77-94. https://doi. org/10.1016/j.jbusvent.2010.07.001

Thompson, E.R., 2009, 'Individual entrepreneurial intent: Construct clarification and development of an internationally reliable metric', Entrepreneurship Theory and Practice 33(3), 669-694. https://doi.org/10.1111/j.1540-6520.2009.00321.x

Ucbasaran, D., Westhead, P. \& Wright, M., 2008, 'Opportunity identification and pursuit: Does an entrepreneur's human capital matter?', Small Business Economics: An Entrepreneurship Journal 30(2), 153-173.

Ucbasaran, D., Westhead, P. \& Wright, M., 2009, 'The extent and nature of opportunity identification by experienced entrepreneurs', Journal of Business Venturing 24(2), 99-115. https://doi.org/10.1007/s11187-006-9020-3

University of Pretoria, 2016, Different forms of survey error, Department of Business Management, University of Pretoria, Pretoria, viewed 07 June 2016, from https:// clickup.up.ac.za.

Weick, K., 1979, The social psychology of organizing, 2nd edn., Sage, Thousand Oaks, CA.

Westhead, P., Ucbasaran, D. \& Wright, M., 2005, 'Decisions, actions, and performance: Do novice, serial, and portfolio entrepreneurs differ?', Journal of Small Business Management 43(4), 393-417. https://doi.org/10.1111/j.1540627X.2005.00144.x

Wihler, A., Blickle, G., Ellen, B.P. III, Hochwarter, W.A. \& Ferris, G.R., 2017, 'Personal initiative and job performance evaluations: Role of political skill in opportunity recognition and capitalization', Journal of Management 43(5), 1388-1420. https://doi.org/10.1177/0149206314552451

Wiklund, J. \& Shepherd, D.A., 2008, 'Portfolio entrepreneurship: Habitual and novice founders, new entry, and mode of organizing', Entrepreneurship Theory and Practice 32(4), 701-725. https://doi.org/10.1111/j.1540-6520.2008.00249.x

Winborg, J. \& Landström, H., 2001, 'Financial bootstrapping in small businesses: Examining small business managers' resource acquisition behaviors', Journal of Business Venturing 16(3), 235-254. https://doi.org/10.1016/S0883-9026(99) 00055-5

Wood, R. \& Bandura, A., 1989, 'Social cognitive theory of organizational management', The Academy of Management Review 14(3), 361-384. https://doi.org/10.5465/ amr.1989.427906

Wright, M., Robbie, K. \& Ennew, C., 1997, 'Serial entrepreneurs', British Journal of Management 8(3), 251-268. https://doi.org/10.1111/1467-8551.00064

Zahra, S.A., Nielsen, A.P. \& Bogner, W.C., 1999, 'Corporate entrepreneurship, knowledge, and competence development', Entrepreneurship Theory and Practice 23(3), 169-189. https://doi.org/10.1177/104225879902300310

Zampetakis, L.A. \& Moustakis, V., 2006, 'Linking creativity with entrepreneurial intentions: A structural approach', The International Entrepreneurship and Management Journal 2(3), 413-428. 